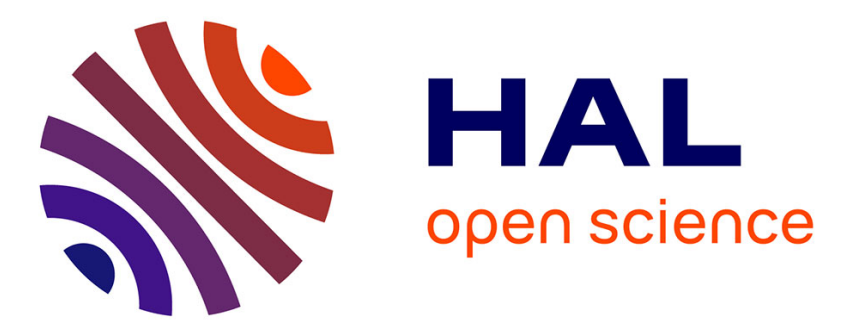

\title{
CoNiMo/Al2O3 sulfide catalysts for dibenzothiophene hydrodesulfurization: Effect of the addition of small amounts of nickel
}

Juan A Medina Cervantes, Rafael Huirache-Acuña, G. Alonso-Núñez, J. N. Díaz de León, S Fuentes Moyado, F. Paraguay-Delgado, G. Berhault

\section{To cite this version:}

Juan A Medina Cervantes, Rafael Huirache-Acuña, G. Alonso-Núñez, J. N. Díaz de León, S Fuentes Moyado, et al.. CoNiMo/Al2O3 sulfide catalysts for dibenzothiophene hydrodesulfurization: Effect of the addition of small amounts of nickel. Microporous and Mesoporous Materials, 2020, 309, pp.110574. 10.1016/j.micromeso.2020.110574 . hal-03443786

\author{
HAL Id: hal-03443786 \\ https://hal.science/hal-03443786
}

Submitted on 23 Nov 2021

HAL is a multi-disciplinary open access archive for the deposit and dissemination of scientific research documents, whether they are published or not. The documents may come from teaching and research institutions in France or abroad, or from public or private research centers.
L'archive ouverte pluridisciplinaire HAL, est destinée au dépôt et à la diffusion de documents scientifiques de niveau recherche, publiés ou non, émanant des établissements d'enseignement et de recherche français ou étrangers, des laboratoires publics ou privés. 


\section{CoNiMo/ $/ \mathrm{Al}_{2} \mathrm{O}_{3}$ Sulfide Catalysts for Dibenzothiophene}

\section{Hydrodesulfurization: Effect of the Addition of Small Amounts of Nickel}

Juan A. Medina Cervantes ${ }^{\mathrm{a}}$, R. Huirache-Acuña ${ }^{\mathrm{a}^{*}}$, G. Alonso-Núñez ${ }^{\mathrm{b}}$ J. N. Díaz de León ${ }^{\mathrm{b}}$, S. Fuentes Moyado ${ }^{\mathrm{b}}$, F. Paraguay-Delgado ${ }^{\mathrm{c}}$, G. Berhault ${ }^{\mathrm{d}}$

${ }^{a}$ Facultad de Ingeniería Quimica, Universidad Michoacana de San Nicolás de Hidalgo, Ciudad Universitaria, C.P. 58060, Morelia, Michoacán, México.

${ }^{b}$ Centro de Nanociencias y Nanotecnología, Universidad Autonoma de México, KM. 107, carretera Tijuana-Ensenada, C.P. 22860, Ensenada, B.C. México.

${ }^{c}$ Centro de Investigación en Materiales Avanzados SC. Avenida Miguel de Cervantes Saavedra 120, Complejo Industrial Chihuahua, 31136 Chihuahua, Chih. Mexico

${ }^{d}$ Institut de Recherches sur la Catalyse et l'Environnement de Lyon, CNRS - Université Lyon I, 02 Avenue Albert Einstein, 69100 Villeurbanne, France

Corresponding Autor: Dr. Rafael Huirache-Acuña

Tel.: +52 4433273584 .

E-Mail: rafael_huirache@yahoo.it 


\section{Abstract}

Trimetallic CoNiMo hydrodesulfurization (HDS) catalysts were herein synthesized on $\mathrm{Al}_{2} \mathrm{O}_{3}$ support through an incipient wetness co-impregnation procedure using ammonium heptamolybdate and cobalt (and nickel) acetate as precursors. CoNiMo catalysts were obtained by adding in a small proportion nickel with molar amount representing between 1 and $10 \%$ of the total Co atomic loading. This addition of low amounts of nickel allows keeping the $(\mathrm{Co}+\mathrm{Ni}) /(\mathrm{Co}+\mathrm{Ni}+\mathrm{Mo})$ molar ratio close to the optimum value of 0.3 . The asformed catalysts were labeled as $\mathrm{CoNi}_{x} \mathrm{Mo} / \mathrm{Al}_{2} \mathrm{O}_{3}$ with $\mathrm{x}$ the relative stoichiometry of $\mathrm{Ni}$ compared to Co. Catalysts were then characterized by $\mathrm{N}_{2}$ adsorption-desorption isotherms, X-ray diffraction, ICP-OES spectroscopy, Raman spectroscopy, scanning electron microscopy, high-resolution transmission electron microscopy, and X-ray photoelectron spectroscopy. Catalysts were tested in the HDS of dibenzothiophene (DBT). Results show a significant impact of adding small amounts of nickel to alumina-supported Co-promoted $\mathrm{MoS}_{2}$ on the final HDS activity. While up to $\mathrm{CoNi} 0.03 \mathrm{Mo} / \mathrm{Al}_{2} \mathrm{O}_{3}$, the resulting HDS activity is hardly influenced by the addition of nickel, a strong beneficial effect is observed for $\mathrm{CoNi} 0.05 \mathrm{Mo} / \mathrm{Al}_{2} \mathrm{O}_{3}$ with an activity reaching a value of $7.2 \times 10^{-7} \mathrm{~mol} \cdot \mathrm{g}_{\mathrm{cat}}{ }^{-1} \cdot \mathrm{s}^{-1}$. Increasing further the amount of nickel abruptly decreased the DBT HDS activity. Interpretation of these results is then provided considering the additional role of nickel for improving the intrinsic activity of the HDS sites.

\section{Keywords}

Trimetallic catalysts; CoNiMo; hydrodesulfurization; dibenzothiophene. 


\section{Introduction}

In recent years, environmental legislation to improve fuel quality has become more and more strict $[1,2]$. The first regulation enforcement was issued in the United States in 1993 to limit the sulfur oxides emission tolerance of transportation vehicles through a reduction from 0.2$0.5 \mathrm{wt} \%$ to $500 \mathrm{ppm}$ in sulfur allowed in diesel fuels [3]. Since then, the Environmental Protection Agency (EPA) has decreased twice the maximum sulfur amount authorized in diesel and gasoline. For instance, the current specification of sulfur amount allowed for onroad diesel fuel is $15 \mathrm{ppm}$ [4-5]. This specification has been extended to non-road engine diesel fuels in 2010. This has triggered increasing request for high quality diesel fuels in developed countries. In this respect, in the US market, demand for high quality diesel has increased from $3.16 \mathrm{Mb} / \mathrm{d}$ (million barrels per day) in 2005 to $3.31 \mathrm{Mb} / \mathrm{d}$ in 2010 . Moreover, light cycle oil (LCO) cuts from fluid catalytic cracking (FCC) units are more and more often used in the diesel pool [6]. This higher LCO proportion increases the difficulty for producing clean diesel products since LCO feeds contain a higher amount of highly refractory sulfur compounds such as alkyldibenzothiophenes.

Nowadays, traditional hydrodesulfurization catalysts cannot produce ultra-low sulfur diesel (ULSD) as required by the latest regulations [7] except if using high temperatures and pressure conditions harmful for catalytic life cycle longevity. To improve deep hydrodesulfurization ability, it is necessary to design new catalysts with enhanced desulfurization activity able to efficiently remove sulfur from highly refractory compounds. New more efficient hydrodesulfurization processes can be obtained through the implementation of new HDS technologies $[8,9]$ or through new catalytic systems using either 
new supports [10-17] or new active phases [18-27], the latter approach being the most promising way to enhance the catalytic HDS efficiency [28]. Traditionally, bimetallic HDS catalysts are composed of $\mathrm{Mo}(\mathrm{W}) \mathrm{S}_{2}$-based solids suported on $\mathrm{Al}_{2} \mathrm{O}_{3}$ and promoted by cobalt or nickel. Bimetallic HDS catalysts are susceptible to thermal, chemical or mechanical degradation and/or metal or coke poisoning which often leads to inefficient ways to treat feedstocks [29-31]. To increase the versatility of catalysts to work in various harmful conditions, investigations have tried to develop trimetallic catalysts such as NiMoW, CoNiW, and CoNiMo. In this respect, some studies have been performed considering CoNiMo catalysts for hydrodesulfurization applications [32-41]. However, contradictory results were obtained about the interest of adding a second promoter for increasing HDS activity. While some contributions found that CoNiMo catalysts are less active than traditional bimetallic systems for the HDS of thiophene [37, 38] and of 4,6-DMDBT [41], other studies have reported higher HDS activity for the CoNiMo combination in the HDS of thiophene [39], dibenzothiophene [35, 40], vacuum gas oil [34] or heavy gasoil [33]. However, up to now, a rational interpretation of the positive (or negative) role devoted to the addition of a second promoter to $\mathrm{MoS}_{2}$-based catalysts has not been proposed yet.

Moreover, the addition of nickel was systematically added in replacement of cobalt in very high amounts with HDS maxima observed at very different $\mathrm{Ni} / \mathrm{Co}$ atomic ratios (from 0.66 for [34] to 1.54 for [35]). This situation is also worsened by the absence of direct experimental proof showing if separate CoMoS and NiMoS phases are separately formed or if new NiCoMoS sites are created, at least partly.

In this respect, one should also consider the affinity of $\mathrm{Ni}$ or Co for the two types of $\mathrm{MoS}_{2}$ edge sites, the so-called S- and M-edge sites. DFT calculations have indeed demonstrated 
that $\mathrm{Co}$ and $\mathrm{Ni}$ act differently when added as promoter sites of $\mathrm{MoS}_{2}$ edge planes. Under typical HDS conditions, Co prefers the S-edge and is only present partially on the M-edge resulting in Co coverages of $100 \%$ on the S-edge and $50 \%$ on the M-edge. On the opposite, $\mathrm{Ni}$ is present on both type of edges with a strong tendency to be incorporated first and only on M-edge sites at low loadings [42-46].

The objective of the present study was therefore to evaluate how the supplementary incorporation of low amounts of nickel in plus of cobalt, on available M-edge sites of $\mathrm{MoS}_{2}$ slabs as proposed by DFT calculations, can influence the textural, structural and catalytic properties of the resulting CoNiMo catalysts. Nickel promoter atoms have then been added in a small proportion in plus of cobalt atoms to form CoNiMo catalysts with a precise control of the amount and nature of the promoters. The resulting trimetallic catalysts have then been fully characterized before being tested in the HDS of dibenzothiophene in order to determine the exact influence of the addition of low amounts of nickel to Co-promoted $\mathrm{MoS}_{2}$ on the final HDS catalytic response.

\section{Experimental}

\subsection{Materials}

Commercial $\mathrm{Al}_{2} \mathrm{O}_{3}$ was purchased from Sasol Germany $\left(\mathrm{S}_{\mathrm{BET}}=200 \mathrm{~m}^{2} / \mathrm{g} ; \mathrm{Vp}=0.85 \mathrm{~cm}^{3} / \mathrm{g}\right.$; average pore diameter: $90 \AA$ A). Dibenzothiophene (98\%), decahydronaphthalene (cis + trans) (98\%), ammonium heptamolybdate tetrahydrate, $\left(\mathrm{NH}_{4}\right)_{6} \mathrm{Mo}_{7} \mathrm{O}_{24.4} \mathrm{H}_{2} \mathrm{O}$, cobalt acetate tetrahydrate $(\geq 98 \%)$ and nickel acetate tetrahydrate $(98 \%)$ were purchased from SigmaAldrich. 


\subsection{Catalysts Synthesis}

$\mathrm{Al}_{2} \mathrm{O}_{3}$-supported catalysts were prepared using an incipient wetness co-impregnation technique. One bimetallic CoMo catalyst supported on alumina and various $\mathrm{Al}_{2} \mathrm{O}_{3}$-supported trimetallic CoNiMo catalysts were synthesized. During the catalyst preparation, the $(\mathrm{Co}) /(\mathrm{Co}+\mathrm{Mo})$ molar ratio was kept constant at 0.3 while small proportions of nickel representing between 1 and $10 \%$ of the cobalt atomic amount were added. Catalysts were labeled as $\mathrm{CoNi} \times \mathrm{Mo} / \mathrm{Al}_{2} \mathrm{O}_{3}$ with $\mathrm{x}$ the theoretical relative stoichiometry of nickel compared tocobalt.

For the bimetallic $\mathrm{CoMo} / \mathrm{Al}_{2} \mathrm{O}_{3}$ catalysts, ammonium heptamolybdate and cobalt acetate tetrahydrate were co-impregnated simultaneously on $\mathrm{Al}_{2} \mathrm{O}_{3}$ followed by drying under air for $2 \mathrm{~h}$ at $393 \mathrm{~K}$ in order to reach nominal weight loadings of Mo and Co respectively of 12.0 and $3.0 \mathrm{wt} \%$. After the drying step, the catalysts were calcined for $4 \mathrm{~h}$ at $773 \mathrm{~K}$ (heating ramp: $2 \mathrm{~K} / \mathrm{min}$ ). The resulting bimetallic oxide catalysts were then sulfided using a $\mathrm{H}_{2} / \mathrm{H}_{2} \mathrm{~S}$ (15\% vol $\left.\mathrm{H}_{2} \mathrm{~S}\right)$ mixture at $673 \mathrm{~K}$ for $2 \mathrm{~h}(20 \mathrm{~mL} / \mathrm{min} ; 5 \mathrm{~K} / \mathrm{min})$.

For the trimetallic $\mathrm{CoNi}_{\mathrm{x}} \mathrm{Mo} / \mathrm{Al}_{2} \mathrm{O}_{3}$ catalysts, nickel was added during the preparation in relative atomic percentages (compared to $\mathrm{Co}$ ) of $1,3,5$, and 10 at $\%$ by adjusting the contents of nickel acetate precursor co-impregnated simultaneously with ammonium heptamolybdate and cobalt acetate onto $\mathrm{Al}_{2} \mathrm{O}_{3}$. The nominal weight percentage of Mo was kept constant at $12.0 \%$. After co-impregnation, solids have been dried for $2 \mathrm{~h}$ at $393 \mathrm{~K}$ before being calcined for $4 \mathrm{~h}$ at $773 \mathrm{~K}$ (heating ramp: $2 \mathrm{~K} / \mathrm{min}$ ). Finally, oxide solids have been activated under a $15 \%$ vol. $\mathrm{H}_{2} \mathrm{~S}$ mixture in $\mathrm{H}_{2}$ for $2 \mathrm{~h}$ at $673 \mathrm{~K}(20 \mathrm{~mL} / \mathrm{min}, 5 \mathrm{~K} / \mathrm{min})$ to obtain the trimetallic sulfide catalysts. 


\subsection{Catalyst Characterization}

A Varian Vista-MPX CCD Simultaneous ICP-OES was used to determine the percentages of $\mathrm{Co}, \mathrm{Ni}$, and $\mathrm{Mo}$ in the sulfided catalysts. An adequate calibration curve with $\pm 10 \%$ uncertainty was prepared for each metal involved in the catalysts.

$\mathrm{N}_{2}$ adsorption-desorption measurements were performed using a Micromeritics GEMINI 2360 equipment. Before analysis, all the samples were degassed under flowing Ar at $423 \mathrm{~K}$ for $2 \mathrm{~h}$. Surface areas were calculated using the Brunauer-Emmett-Teller method while the Barrett-Joyner-Halenda $(\mathrm{BJH})$ model was used for pore size determination considering the desorption branch of $\mathrm{N}_{2}$ isotherms.

X-ray diffraction (XRD) patterns were recorded using a PANalytical X'pert MPD diffractometer equipped with a curved graphite monochromator using the $\mathrm{Cu} K \alpha$ radiation ( $\lambda$ $=1.54056 \AA$ ), a Ni filter and an $X^{\prime}$ Celerator detector. Patterns were acquired in the $5^{\circ}-80^{\circ}$ $2 \theta$ range.

Raman spectra were collected on oxide samples using a Renishaw inVia spectrometer equipped with a Nd:YAG laser $(\lambda=532 \mathrm{~nm})$. A 1200 lines/mm grating monochromator was used to scatter photons which are then collected on a CCD camera. The spectra resolution was $1 \mathrm{~cm}^{-1}$.

Solids were also analyzed by scanning electron microscopy (SEM) using a JEOL JSM-5300 microscope. Before analysis, samples were deposited on a sample holder with conductive carbon double-sided tape. Samples were observed at $15 \AA$ and $30 \mathrm{kV}$. Several regions were 
analyzed at different magnifications $(500,2000$ and $5000 \mathrm{x})$ to get a complete surface information.

Transmission electron microscopy (TEM) images were obtained using a JEOL JEM-2200FS $(200 \mathrm{kV})$ microscope in order to get information about $\mathrm{MoS}_{2}$ slab length and stacking degree. Several zones on the micrographs were observed to perform a statistical analysis of $\mathrm{MoS}_{2}$ slabs. Samples were ultrasonically dispersed in ethanol before being deposited onto a carboncoated $\mathrm{Cu}$ grid. Average stacking number and average slab lengths were determined as follows:

$$
\begin{gathered}
\bar{N}=\frac{\sum_{i=1}^{n} n_{i} N_{i}}{\sum_{i=1}^{n} n_{i}} \\
\bar{L}=\frac{\sum_{i=1}^{n} n_{i} l_{i}}{\sum_{i=1}^{n} n_{i}}
\end{gathered}
$$

With $N_{\mathrm{i}}$ and $l_{i}$ corresponding respectively to the stacking number and the length of a $\mathrm{MoS}_{2}$ slab, $n_{i}$ the number of particles measured in a size range or stacking number of index $i$.

XPS analyses were performed using a SPECS ${ }^{\circledR}$ spectrometer equipped with a PHOIBOS ${ }^{\circledR}$ 150 WAL hemispherical energy analyzer with angular resolution lower than $0.5^{\circ}$. The XPS apparatus also possesses a $\mu$-FOCUS $500 \mathrm{X}$-ray monochromator (Al excitation line). For the sulfide samples, transfer to the XPS chamber was performed under Ar and without contact with air to avoid re-oxidation. Binding energies were referenced to the adventitious $\mathrm{C}$ 1s peak (284.8 eV). Background subtraction was performed using a Shirley baseline while mixed Gaussian/Lorentzian functions were used to fit core-level spectra. 


\subsection{Catalytic Activity}

HDS of dibenzothiophene (DBT) was performed using a high-pressure batch Parr reactor with $0.25 \mathrm{~g}$ of catalyst. Particle granulometry was selected between 80 and 120 mesh to avoid diffusional limitations. A solution of $2.7 \mathrm{~g}$ of DBT in $75 \mathrm{~mL}$ of decahydronaphthalene (cis + trans mixture) was used. The reactor was first heated at $623 \mathrm{~K}$ under $690 \mathrm{kPa}$ of $\mathrm{H}_{2}$ before being purged. This purging procedure was repeated three times. The final pressure was then fixed at 44.8 bars of $\mathrm{H}_{2}$. Note that HDS conversion and selectivity results are independent of the $\mathrm{H}_{2}$ pressure above $\mathrm{P}_{\mathrm{H} 2}=5$ bars [47]. Stirring rate was set at $400 \mathrm{rpm}$ to avoid external diffusion limitations. Initial time was fixed when agitation started at the final temperature and pressure conditions. Samples were retrieved every 30 minutes before being analyzed to determine the evolution of the HDS conversion in function of reaction time. The mean standard deviation for catalytic measurements was about $2.5 \%$ [48]. The analysis was performed using an Agilent 7890A gas chromatograph equipped with an HP5 capillary column (30 m length x $0.32 \mathrm{~mm}$ internal diameter x $0.25 \mu \mathrm{m}$ thickness) and an Agilent 355 sulfur chemiluminescence detector $(\mathrm{SCD})$. The reaction products detected by gas chromatography were biphenyl (BP), cyclohexylbenzene (CHB), dicyclohexyl (DCH), and tetrahydrodibenzothiophene (THDBT). The catalytic activity was expressed by the initial reaction rate which was determined from DBT conversion (ХDBT) as a function of time (molDBT transformed per second and per gram of catalyst). The HYD/DDS selectivity ratio was calculated according to HYD and DDS routes products as follows: $[(\mathrm{THDBT}+\mathrm{CHB}+\mathrm{DCH})] / \mathrm{BP}$. 


\section{Results and Discussion}

\subsection{Characterization at the Oxide State}

\subsection{1. $\mathrm{N}_{2}$ Physisorption}

Figure 1a reports the $\mathrm{N}_{2}$ adsorption-desorption isotherms of the $\mathrm{CoMo} / \mathrm{Al}_{2} \mathrm{O}_{3}$ reference catalyst and of the $\mathrm{CoNi} \mathrm{x}_{\mathrm{x}} \mathrm{Mo} / \mathrm{Al}_{2} \mathrm{O}_{3}$ solids. The isotherms present almost identical type IV profiles characteristic of a mesoporous distribution. Hysteresis loops are well-defined and do not differ from one sample to the next one exhibiting a type H1 shape corresponding either to particles crossed by nearly cylindrical channels or made of aggregates or agglomerates of spheroidal particles $[48,49]$. Table 1 reports the textural properties of the $\mathrm{CoMo} / \mathrm{Al}_{2} \mathrm{O}_{3}$ reference and of the various $\mathrm{CoNi} \mathrm{i}_{\mathrm{x}} \mathrm{Mo} / \mathrm{Al}_{2} \mathrm{O}_{3}$ solids. BET specific surface areas do not present substantial variations with the increase of the relative $\mathrm{Ni}$ atomic content in the CoNiMo

catalysts with values ranging between 152 and $176 \mathrm{~m}^{2} / \mathrm{g}$. This result shows that modifying the nature of the promoter used (at least in the relative range of this study) does not influence the final textural properties achieved after co-impregnation on the $\mathrm{Al}_{2} \mathrm{O}_{3}$ support. This is also confirmed by the pore volume values which remain relatively constant around $0.50 \mathrm{~cm}^{3} / \mathrm{g}$ whatever the relative cobalt and nickel loadings. Figure $1 \mathrm{~b}$ also reports the BJH pore size distribution observed for all the catalysts. In all cases, identical profiles are obtained showing pore diameter values around 84-87 Å.

\subsubsection{X-ray Diffraction}

CoMo and $\mathrm{CoNi}_{x} \mathrm{Mo}$ solids supported on $\mathrm{Al}_{2} \mathrm{O}_{3}$ were also analyzed by $\mathrm{X}$-ray diffraction at the oxide state after calcination at $773 \mathrm{~K}$ for $4 \mathrm{~h}$. All the samples present poorly crystalline structures with only weak diffraction peaks (Figure 2). However, the characterization peaks 
of the $\gamma-\mathrm{Al}_{2} \mathrm{O}_{3}$ phase can be observed at $2 \theta$ values of $32^{\circ}, 37^{\circ}, 45^{\circ}$, and $66^{\circ}$ corresponding to the (200), (311), (400), and (440) planes respectively [50]. One should also note the absence of any peaks corresponding to segregated $\mathrm{Ni}$ or Co oxide phases. All solids also exhibit a distinct diffraction peak at $23.4^{\circ}$ corresponding to the $\mathrm{MoO}_{3}$ phase [51]. Moreover, this peak presents some variations in intensity being the most intense for $\mathrm{CoNi} 0.01 \mathrm{Mo} / \mathrm{Al}_{2} \mathrm{O}_{3}$ before decreasing slightly at higher $\mathrm{Ni}$ contents (mainly for $\mathrm{CoNi} 0.05 \mathrm{Mo} / \mathrm{Al}_{2} \mathrm{O}_{3}$ and CoNio.1 $\mathrm{Mo} / \mathrm{Al}_{2} \mathrm{O}_{3}$ ) suggesting that a small addition of nickel can favor the formation of a more crystalline $\mathrm{MoO}_{3}$ phase. This point will be further studied by Raman spectroscopy. Another clear diffraction peak can also be noticed at $2 \theta=26.5^{\circ}$ accompanied by a weaker contribution at $2 \theta=28.4^{\circ}$. These peaks are generally attributed to the presence of a cobalt molybdate phase, $\beta-\mathrm{CoMoO}_{4}[52,53]$ which is known to reduce the ability to form a cobaltpromoted $\mathrm{MoS}_{2}$ phase after sulfidation [54-56]. However, the intensity of the cobalt molybdate species does not change whatever the amount of nickel added in plus of cobalt to promote the $\mathrm{MoS}_{2}$ catalysts suggesting that the cobalt molybdate phase is present in a similar amount and that it should marginally influence the final sulfided state, all other conditions being equal.

\subsubsection{Raman Spectroscopy}

The various $\mathrm{CoNi} \mathrm{x}_{\mathrm{x}} \mathrm{Mo}$ catalysts supported on $\mathrm{Al}_{2} \mathrm{O}_{3}$ were also analyzed by Raman spectroscopy to determine the influence of the addition of nickel on the dispersion and nature of the molybdenum oxide species formed. For comparison purposes, the reference $\mathrm{CoMo} / \mathrm{Al}_{2} \mathrm{O}_{3}$ catalyst was also studied. For the Ni-free sample, four main vibration bands 
can be observed at $360 \mathrm{~cm}^{-1}, 820 \mathrm{~cm}^{-1}, 875 \mathrm{~cm}^{-1}$ (weak), and $940-960 \mathrm{~cm}^{-1}$ (Figure 3). The bands at 360 and $820 \mathrm{~cm}^{-1}$ were assigned respectively to the deformation and asymmetric stretching modes of $\mathrm{MoO}_{3}$ species while the bands at 875 and $940-960 \mathrm{~cm}^{-1}$ are due to the asymmetric and symmetric stretching modes of polymolybdate species [33, 57-59]. For $\mathrm{CoNi} 0_{0.01} \mathrm{Mo} / \mathrm{Al}_{2} \mathrm{O}_{3}$, a clear distinguishable new vibration band due to $\mathrm{MoO}_{3}$ clustering into large polymerized entities appears at $995 \mathrm{~cm}^{-1}[58,59]$ suggesting that the addition of even a small amount of nickel has significant consequences in terms of molybdenum oxide species. This result confirms the preceding observations made by X-ray diffraction. The effect of such a small amount of nickel on the structure of molybdenum oxide species suggest here that this low nickel content probably triggers the condensation of polymolybdate species in such a way that large clusters of $\mathrm{MoO}_{3}$ are formed after calcination.

This situation however changes when increasing the amount of nickel to $3 \%$ and $5 \%$ suggesting a different role of nickel at these higher $\mathrm{Ni}$ contents. Indeed, a progressive disappearance of the signal due to $\mathrm{MoO}_{3}$ clustered species at $995 \mathrm{~cm}^{-1}$ is now observed giving rise only to a shoulder for $\mathrm{CoNi} 0_{0.03} \mathrm{Mo} / \mathrm{Al}_{2} \mathrm{O}_{3}$ and disappearing completely for $\mathrm{CoNi}{ }_{0.05} \mathrm{Mo} / \mathrm{Al}_{2} \mathrm{O}_{3}$. This is also accompanied by a shift of the maximum of the main band due to polymolybdate entities from 940 to $960 \mathrm{~cm}^{-1}$ when increasing the nickel content from 1 to $3 \%$. This indicates a progressive higher polymerization degree of the molybdate species from a mixture of $\mathrm{MoO}_{4}{ }^{2-}$ and $\mathrm{Mo}_{7} \mathrm{O}_{24}{ }^{6-}$ species for $\mathrm{CoNi} 0.01 \mathrm{Mo} / \mathrm{Al}_{2} \mathrm{O}_{3}$ to almost only heptamolybdate entities for $\mathrm{CoNi} 0.03 \mathrm{Mo} / \mathrm{Al}_{2} \mathrm{O}_{3}$ and $\mathrm{CoNi} 0.05 \mathrm{Mo} / \mathrm{Al}_{2} \mathrm{O}_{3}$. Increasing further the Ni content to $10 \%$ leads to a partial loss of defined bands suggesting a higher heterogeneity in terms of molybdate species with a main contribution around $960 \mathrm{~cm}^{-1}$. This latter band 
appears also much broader particularly for the higher Raman shift values suggesting the reappearance of some $\mathrm{MoO}_{3}$ clusters in this case but in a lower proportion.

\subsubsection{Scanning Electron Microscopy}

Figure 4 reports the SEM images acquired for the $\mathrm{CoMo} / \mathrm{Al}_{2} \mathrm{O}_{3}$ catalyst without $\mathrm{Ni}$ and for the $\mathrm{CoNi} \mathrm{Mo}_{\mathrm{x}} / \mathrm{Al}_{2} \mathrm{O}_{3}$ solids with nickel varying between 1 and $10 \mathrm{wt} \%$ of the total initial Co amount. The aspect of all the solids appear similar with a relatively compact shape and the

presence in all cases of small grains spread onto the alumina matrix. These results are in agreement with textural properties showing that the addition of small amount of Ni in plus of Co does not influence significantly the porosity and specific surface areas of the aluminasupported $\mathrm{Co}(\mathrm{Ni}) \mathrm{Mo}$ catalysts.

\subsection{Characterization at the Sulfide State}

\subsubsection{Transmission Electron Microscopy}

In order to determine how the nature and dispersion of the Mo species at the oxide state may influence the final dispersion of the active phase at the sulfide state, TEM images were acquired for three different cases: 1) the $\mathrm{CoMo} / \mathrm{Al}_{2} \mathrm{O}_{3}$ reference without nickel, 2) the $\mathrm{CoNi} 0.05 \mathrm{Mo} / \mathrm{Al}_{2} \mathrm{O}_{3}$ solid with an intermediate amount of nickel, and 3) the $\mathrm{CoNi} 0.1 \mathrm{Mo} / \mathrm{Al}_{2} \mathrm{O}_{3}$ solid with the highest nickel content (Figure 5). All images show the presence of $\mathrm{MoS}_{2} \mathrm{slabs}$ with characteristic fringes separated by a $0.65 \mathrm{~nm}$ interlayer spacing as expected for the $2 \mathrm{H}-$ $\mathrm{MoS}_{2}$ phase $[60,61]$. Statistical analysis was then performed in different regions of the solids in order to determine the average slab length and average stacking number of each catalyst. Results are reported in Table 2. The evolution of the average slab length of $\mathrm{MoS}_{2}$ slabs in 
function of the $\mathrm{Ni}$ content shows an increase of the slab length from $4.7 \mathrm{~nm}$ for $\mathrm{CoMo} / \mathrm{Al}_{2} \mathrm{O}_{3}$ to $4.9 \mathrm{~nm}$ for $\mathrm{CoNi} 0.05 \mathrm{Mo} / \mathrm{Al}_{2} \mathrm{O}_{3}$ and $5.4 \mathrm{~nm}$ for $\mathrm{CoNi} 0.1 \mathrm{Mo} / \mathrm{Al}_{2} \mathrm{O}_{3}$. The determination of the stacking degree shows similar values for the $\mathrm{CoMo} / \mathrm{Al}_{2} \mathrm{O}_{3}$ and $\mathrm{CoNi}{ }_{0.05} \mathrm{Mo} / \mathrm{Al}_{2} \mathrm{O}_{3}$ solids (1.83-1.86) while the sample with the highest Ni content $\left(\mathrm{CoNi} .1 \mathrm{Mo} / \mathrm{Al}_{2} \mathrm{O}_{3}\right)$ presents more stacked slabs (2.23). This shows a progressive but moderate decrease of the dispersion of the $\mathrm{MoS}_{2}$ slabs as the nickel content increases in the $\mathrm{Co}(\mathrm{Ni}) \mathrm{Mo}$ catalysts with a more marked effect on both average slab length and stacking for the sample with the highest Ni content. This can be compared to our previous Raman results acquired at the oxide state showing a higher propensity of CoNiMo to form $\mathrm{MoO}_{3}$ clusters. This emphasizes a direct correlation between the ability to disperse molybdenum oxide species and the final dispersion of the $\mathrm{MoS}_{2}$ slabs.

\subsubsection{ICP-OES Analysis}

ICP-OES analysis was also performed at the sulfide state to determine the real experimental contents of Ni, Co and Mo. Results are reported in Table 3 for the $\mathrm{CoMo} / \mathrm{Al}_{2} \mathrm{O}_{3}$ reference and for all the $\mathrm{CoNi} \times \mathrm{Mo} / \mathrm{Al}_{2} \mathrm{O}_{3}$ samples. Mo and $\mathrm{Co}$ amounts remain relatively constant for all the samples with values around 3.5-3.8 $\mathrm{wt} \%$ for Co and $15.8-16.9 \mathrm{wt} \%$ for Mo. Note that these values are slightly different to the nominal loading at the oxide state due to the sulfidation procedure. About nickel, experimental values are lower than theoretical ones at very low loadings, slightly for $\mathrm{CoNi} 0.01 \mathrm{Mo} / \mathrm{Al}_{2} \mathrm{O}_{3}$ and more significantly for CoNio.03 $\mathrm{Mo} / \mathrm{Al}_{2} \mathrm{O}_{3}$. However, at higher Ni loadings, the experimental values for the $\mathrm{Ni}$ content are very close to the theoretical ones showing some difficulties to incorporate nickel inside cobalt-promoted $\mathrm{MoS}_{2}$ samples when nickel loadings are very low. However, this 
difficulty is relieved at higher nickel contents. In terms of $(\mathrm{Co}+\mathrm{Ni}) /(\mathrm{Co}+\mathrm{Ni}+\mathrm{Mo})$ molar ratios, values are relatively constant and close to the 0.3 optimized value for promotion.

\subsubsection{X-ray Photoelectron Spectroscopy}

$\mathrm{X}$-ray photoelectron spectra have also been acquired for the $\mathrm{CoMo} / \mathrm{Al}_{2} \mathrm{O}_{3}$ reference catalyst and for all the Ni-containing alumina-supported $\mathrm{CoNi}_{\mathrm{x}} \mathrm{Mo}$ solids. Note first that due to the low amount of nickel added, this element could not be detected by XPS except for the richest $\mathrm{Ni}$-containing sample $\left(\mathrm{CoNi} 0.1 \mathrm{Mo} / \mathrm{Al}_{2} \mathrm{O}_{3}\right)$ but still with a too weak signal to allow performing a decomposition procedure into different nickel species. Therefore, only the Mo $3 \mathrm{~d}$ and Co $2 p$ core level spectra have been analyzed in order to determine the proportion of the different Mo and Co species formed at the sulfide state. Examples of decomposition procedures of Mo $3 \mathrm{~d}$ and $\mathrm{Co} 2 \mathrm{p}$ core level spectra are provided in Figure 6 about the $\mathrm{CoNi}{ }_{0.05} \mathrm{Mo} / \mathrm{Al}_{2} \mathrm{O}_{3}$ catalyst. Mo 3d spectra decomposition procedure has been extensively reported in [62-64]. The Mo $3 \mathrm{~d}$ core-level spectra region comprises Mo $3 \mathrm{~d}_{5 / 2}$ and Mo $3 \mathrm{~d}_{3 / 2}$ contributions. Three Mo $3 \mathrm{~d}$ doublets can be found: 1) a doublet with binding energies at 229.0 and $232.0 \mathrm{eV}$ corresponding to Mo IV species of the molybdenum sulfide phase, 2) two Mo 3d5/2 and Mo $3 \mathrm{~d}_{3 / 2}$ contributions at 230.0 and $233.4 \mathrm{eV}$ due to Mo oxysulfide species with a $+\mathrm{V}$ oxidation state and finally 3) a doublet at 232.1 and $235.3 \mathrm{eV}$ corresponding to Mo +VI species of molybdenum oxide. Finally, one should note the presence at lower binding energy values of the S 2s core level contributions. Mo 3d decomposition results are reported in Table 4. In the case of $\mathrm{CoNi}{ }_{0.01} \mathrm{Mo} / \mathrm{Al}_{2} \mathrm{O}_{3}$, adding $\mathrm{Ni}$ leads to a marked increase in the proportion of molybdenum oxysulfide species from $8.3 \%$ for $\mathrm{CoMo} / \mathrm{Al}_{2} \mathrm{O}_{3}$ to $30.2 \%$ for CoNio.01 Mo/ $\mathrm{Al}_{2} \mathrm{O}_{3}$ while the $\mathrm{MoS}_{2}$ phase proportion decreases significantly to $64.7 \%$ from 
$82.5 \%$ for $\mathrm{CoMo} / \mathrm{Al}_{2} \mathrm{O}_{3}$. Increasing further the $\mathrm{Ni}$ content confirms a progressive higher difficulty to sulfide the molybdenum species. Indeed, for $\mathrm{CoNi}_{0.03} \mathrm{Mo}_{/} \mathrm{Al}_{2} \mathrm{O}_{3}$, instead of an increased proportion of partially-sulfided Mo oxysulfides, a higher proportion of completely non-sulfided Mo oxide species can be noticed ( $15.9 \%$ vs $5.1 \%$ for $\left.\mathrm{CoNi} 0.01 \mathrm{Mo} / \mathrm{Al}_{2} \mathrm{O}_{3}\right)$. However, increasing further the nickel content like for $\mathrm{CoNi} 0.05 \mathrm{Mo} / \mathrm{Al}_{2} \mathrm{O}_{3}$ and $\mathrm{CoNi} .1 \mathrm{Mo} / \mathrm{Al}_{2} \mathrm{O}_{3}$ does not modify significantly anymore the proportion of Mo oxide species. One should also note that this increase in Mo oxide species occurs at the expense of Mo oxysulfide species decreasing once again to low percentages between $5.9 \%$ and $8.0 \%$. Finally, the proportion of completely sulfided Mo species goes back progressively to values close to the one observed for the $\mathrm{Ni}$-free $\mathrm{CoMo} / \mathrm{Al}_{2} \mathrm{O}_{3}$ catalyst. In this respect, the proportions in $\mathrm{MoS}_{2}$ phase for $\mathrm{CoNi} 0.05 \mathrm{Mo} / \mathrm{Al}_{2} \mathrm{O}_{3}$ and $\mathrm{CoNi} 0.1 \mathrm{Mo} / \mathrm{Al}_{2} \mathrm{O}_{3}$ are 81.2 and $79.3 \%$ respectively, close to $82.5 \%$ for $\mathrm{CoMo} / \mathrm{Al}_{2} \mathrm{O}_{3}$.

Results about the Co $2 \mathrm{p}$ decomposition core level spectra are also reported in Table 4. The Co $2 p_{3 / 2}$ core level spectrum also comprises three different contributions with their respective satellites [65-67] corresponding to $\mathrm{CoO}_{\mathrm{x}}$ oxide species, the promoted $\mathrm{CoMoS}$ phase and the non-promoted $\mathrm{CoS}_{\mathrm{x}}$ sulfide species. $\mathrm{CoO}_{\mathrm{x}}, \mathrm{CoMoS}$, and $\mathrm{CoS}_{\mathrm{x}}$ species give rise to $\mathrm{Co} 2 \mathrm{p}_{3 / 2}$ contributions at binding energies respectively around $782 \mathrm{eV}, 778.3-778.9 \mathrm{eV}$, and 777.6$777.9 \mathrm{eV}[68,69]$. Results show that the CoNix Mo samples are slightly better sulfided than the $\mathrm{CoMo} / \mathrm{Al}_{2} \mathrm{O}_{3}$ reference except for the richest Ni-containing $\mathrm{CoNi} 0.1 \mathrm{Mo} / \mathrm{Al}_{2} \mathrm{O}_{3}$ catalyst. Moreover, for nickel contents up to the $\mathrm{CoNi} 0.05 \mathrm{Mo} / \mathrm{Al}_{2} \mathrm{O}_{3}$ case, the proportion of promoted CoMoS phase does not change significantly remaining between 64 and $69 \%$. The only exception is the $\mathrm{CoNi}{ }_{0.1} \mathrm{Mo} / \mathrm{Al}_{2} \mathrm{O}_{3}$ system which presents significant increases in $\mathrm{CoO}_{\mathrm{x}}$ and 
non-promoted $\operatorname{CoS}_{\mathrm{x}}$ species, respectively to 16.2 and $27.0 \%$ while the lowest percentage of promoted phase was also found for this sample (56.8 \%).

The Mo $3 \mathrm{~d}$ and Co $2 \mathrm{p}$ XPS results correlate nicely with Raman results at the oxide state. Indeed, for $\mathrm{CoNi} 0.01 \mathrm{Mo} / \mathrm{Al}_{2} \mathrm{O}_{3}$, the appearance of a significant $\mathrm{MoO}_{3}$ contribution leads to a higher difficulty to sulfidation with the lowest percentage of $\mathrm{MoS}_{2}$ phase and a higher proportion of incompletely sulfided Mo oxysulfides. Increasing the nickel content like for CoNio.03 Mo/ $\mathrm{Al}_{2} \mathrm{O}_{3}$ and $\mathrm{CoNi} .05 \mathrm{Mo} / \mathrm{Al}_{2} \mathrm{O}_{3}$ leads back progressively to better completely sulfided $\mathrm{MoS}_{2}$ species while the percentage of promoted phase does not change in agreement with the progressive disappearance of agglomerated $\mathrm{MoO}_{3}$ clusters at the oxide state. Finally, the reappearance of $\mathrm{MoO}_{3}$ clusters for the $\mathrm{CoNi} 0.1 \mathrm{Mo} / \mathrm{Al}_{2} \mathrm{O}_{3}$ case induces this time a lower formation of the Co-promoted phase suggesting in this latter case that a too high addition of nickel would lead to a competition between $\mathrm{Ni}$ and $\mathrm{Co}$ for accommodating $\mathrm{MoS}_{2}$ edge planes.

\subsection{HDS Catalytic Activity Evaluation}

The evolution of the initial reaction rate for the hydrodesulfurization of dibenzothiophene in function of the Ni content show a marked and contrasted evolution of the HDS activity with the amount of nickel present (Table 5). For $\mathrm{CoNi} 0.01 \mathrm{Mo} / \mathrm{Al}_{2} \mathrm{O}_{3}$, the activity tends to decrease slightly to $5.9 \times 10^{-7}$ moldвт. gcat $^{-1} . \mathrm{s}^{-1}$ from $6.3 \times 10^{-7}$ moldвт. gcat $^{-1} \cdot \mathrm{s}^{-1}$ for the $\mathrm{CoMo} / \mathrm{Al}_{2} \mathrm{O}_{3}$ reference. This limited decrease can be ascribed to the lower sulfidation degree of the molybdenum species as shown by XPS. This moderate loss of activity cannot be retrieved when increasing the $\mathrm{Ni}$ content like for $\mathrm{CoNi} 0.03 \mathrm{Mo} / \mathrm{Al}_{2} \mathrm{O}_{3}$. This can be due probably to a still too high proportion of $\mathrm{MoO}_{\mathrm{x}}$ species (Table 4) confirming the difficulty to sulfide the $\mathrm{MoO}_{3}$ clusters observed at the oxide state (Figure 3). On the opposite, increasing further the nickel 
amount to $5 \%\left(\mathrm{CoNi}_{0.05} \mathrm{Mo} / \mathrm{Al}_{2} \mathrm{O}_{3}\right)$ leads to a net increase of the HDS activity to $7.2 \times 10^{-7}$ molDBT. $g_{\text {cat }}{ }^{-1} \cdot \mathrm{s}^{-1}$. This reflects the optimized preparation achieved in this case without significant $\mathrm{MoO}_{3}$ clustering (Figure 3) and with a high proportion of $\mathrm{MoS}_{2}$ species (81.2\%). This is also accompanied by the maintaining of the promoted CoMoS phase to a proportion similar to the nickel-free $\mathrm{CoMo} / \mathrm{Al}_{2} \mathrm{O}_{3}$ reference. Markedly, the $\mathrm{CoNi} 0.1 \mathrm{Mo} / \mathrm{Al}_{2} \mathrm{O}_{3}$ sample with the richest $\mathrm{Ni}$ content shows the lowest HDS activity, much lower even than the $\mathrm{CoMo} / \mathrm{Al}_{2} \mathrm{O}_{3}$ reference $\left(3.8 \times 10^{-7}\right.$ molDBT. $\left.\mathrm{g}_{\mathrm{cat}}{ }^{-1} \cdot \mathrm{s}^{-1}\right)$. This is directly related here to the lowest proportion of promoted phase as determined by XPS for this sample $(56.8 \%)$.

The hydrodesulfurization of dibenzothiophene also occurs through two parallel pathways: 1) the direct desulfurization route (DDS) leading to direct C-S bond rupture and formation of biphenyl and 2) the so-called hydrogenating route (HYD) in which hydrogenation of one of the two aromatic rings occurs before C-S hydrogenolysis leading to cyclohexylbenzene. Table 5 reports the HYD/DDS ratio observed for each catalyst. Results show similar $\mathrm{HYD} / \mathrm{DDS}$ ratios in all cases with the noticeable exception of $\mathrm{CoNi} 0.05 \mathrm{Mo} / \mathrm{Al}_{2} \mathrm{O}_{3}$ with a HYD/DDS ratio of 0.39 . This indicates that in this particular case the promoted active sites are more hydrogenating in character suggesting that the successful incorporation of nickel into Co-doped $\mathrm{MoS}_{2}$ slabs as observed in this case can modify partly the selectivity properties without decreasing both the degree of sulfidation and the amount of CoMoS phase.

The HDS results should also be analyzed taking into account the fact that the $\mathrm{MoS}_{2}$ dispersion also varies when increasing the nickel content. In this respect, the determination of turnover frequency (TOF) values allow evaluating the relative intrinsic activities of the previous catalysts and the enhancement of the catalytic efficiency resulting from the incorporation of nickel into cobalt-promoted $\mathrm{MoS}_{2}$ catalysts independently of the dispersion parameter. TOF 
values are determined considering a geometrical model for $\mathrm{MoS}_{2}$ slabs [59] in which the total number of Mo atoms in the slabs and the number of Mo edge atoms (considered as the only active HDS sites) are obtained as follows:

$\mathrm{Mot}_{\mathrm{t}}=3 \mathrm{n}^{2}+3 \mathrm{n}+1$

$\mathrm{Mo}_{\mathrm{e}}=6 \mathrm{n}$

With $\mathrm{n}(\AA)=\frac{L}{2 \times 3.2}\left(\mathrm{~L}=\right.$ slab length, and $\left.\mathrm{d}_{\mathrm{Mo}-\mathrm{Mo}}=3.2 \AA\right)$.

Slab lengths are determined by TEM statistical analysis while the number of $\mathrm{MoS}_{2}$ edge sites can be calculated considering the Mo loading as determined by ICP-OES and the $\mathrm{MoS}_{2}$ proportion obtained by XPS. TOF values are then obtained as follows:

$\operatorname{TOF}\left(\mathrm{h}^{-1}\right)=\mathrm{r} . N / \mathrm{n}(\operatorname{MoS} 2 \mathrm{e})$

with $\mathrm{r}$, the DBT activity at $623 \mathrm{~K}, N$ the Avogadro number and $\mathrm{n}$ (MoS2e) the number of Mo edge atoms as $\mathrm{MoS}_{2}$.

Results are herein determined for three cases: the $\mathrm{CoMo} / \mathrm{Al}_{2} \mathrm{O}_{3}$ reference, the most active catalyst, $\mathrm{CoNi} 0.05 \mathrm{Mo} / \mathrm{Al}_{2} \mathrm{O}_{3}$, and finally the richest $\mathrm{Ni}$ containing $\mathrm{CoNi} 0.1 \mathrm{Mo} / \mathrm{Al}_{2} \mathrm{O}_{3}$. Going from the $\mathrm{CoMo} / \mathrm{Al}_{2} \mathrm{O}_{3}$ reference to $\mathrm{CoNi}{ }_{0.05} \mathrm{Mo} / \mathrm{Al}_{2} \mathrm{O}_{3}$, TOF values increase from $7.0 \mathrm{~h}^{-1}$ to $7.9 \mathrm{~h}^{-1}$ showing an enhancement by $\sim 15 \%$ of the intrinsic activity resulting from an optimized incorporation of $\mathrm{Ni}$ into a cobalt-promoted $\mathrm{Al}_{2} \mathrm{O}_{3}$ catalyst. This underlines clearly that the controlled incorporation of even quite low amounts of nickel increases the intrinsic activity of HDS catalysts.

In this respect, when comparing $\mathrm{CoNi} 0.05 \mathrm{Mo} / \mathrm{Al}_{2} \mathrm{O}_{3}$ to the $\mathrm{CoMo} / \mathrm{Al}_{2} \mathrm{O}_{3}$ reference, the enhanced activity cannot be attributed neither to a higher dispersion of the active phase (cf. Table 2) nor to a higher sulfidation degree or proportion of CoMoS phase (cf. Table 4). 
Therefore, and since the Co content is similar in both cases, the HDS enhancement should only result from the incorporation of $\mathrm{Ni}$ onto the M-edge sites of $\mathrm{MoS}_{2}$ slabs since not occupied by cobalt and creating therefore new NiMoS sites, as suggested by various DFT studies [42-46]. A rough approximation can then be made about the intrinsic activity of such NiMoS sites considering that all the Ni atoms are incorporated onto the $\mathrm{MoS}_{2}$ edge sites. The resulting increased HDS activity compared to $\mathrm{CoMo} / \mathrm{Al}_{2} \mathrm{O}_{3}$ would indicate that these new NiMoS sites are about $60 \%$ more active than the CoMoS sites. Note however that these CoMoS sites are not expected to present similar intrinsic activities since comprising a majority of sites on the S-edge planes but also a minority on the M-edge sites. This should lead to different intrinsic activities for these CoMoS sites depending on their location on the edge planes. Anyway, this result, even if approximate, confirms that the additional incorporation of $\mathrm{Ni}$ atoms on $\mathrm{M}$-edge sites in plus of Co promoters results in the formation of highly active promoted active sites.

Increasing further the nickel content to about $10 \%$ like for $\mathrm{CoNi} 0.1 \mathrm{Mo} / \mathrm{Al}_{2} \mathrm{O}_{3}$ leads to a strong decrease of the TOF value to $4.7 \mathrm{~h}^{-1}$. This low intrinsic activity results mainly from a significant decrease of the proportion of CoMoS phase as observed by XPS (Table 4). This would suggest that at higher Ni loading, nickel has a stronger affinity for the M-edge sites of $\mathrm{MoS}_{2}$ slabs $[45,46]$. Nickel then starts competing with cobalt for the occupation of the Medge planes. This results in a loss of CoMoS phase. This also suggests that the Co-promoted sites present on the M-edge planes are intrinsically more active than the more numerous CoMoS entities present on the S-edge planes since otherwise no decrease in activity would have been observed. This result is in agreement with previous DFT observations showing that the maximum HDS activity is reached when an optimum amount of Co is present on the 
M-edge sites pointing to the superior activity of CoMoS sites when formed on M-edge planes $[46,60]$. This was also confirmed recently by Ding et al. [70] through DFT calculations. Indeed, the C-S hydrogenolysis ability of the Co-promotion on M-edge planes was found intrinsically more efficient than on S-edge sites.

\section{Conclusion}

In the present study, the influence of incorporating low amounts of nickel into cobaltpromoted $\mathrm{MoS}_{2}$ catalysts was herein evaluated. Nickel was incorporated in relative proportions of $1,3,5$ or 10 atomic percentages of the cobalt initially present. The resulting catalysts were characterized at both the oxide and sulfide states showing that optimum conditions of preparation were reached when about $5 \%$ of nickel was added in plus of cobalt. Before and after this optimum, substantial $\mathrm{MoO}_{3}$ clustering is observed at the oxide state leading either to difficulties for sulfiding the molybdenum species at very low Ni loadings or to a lower formation of the promoted phase if nickel is added in excess. HDS optimum efficiency is therefore reached for the $\mathrm{CoNi} 0.05 \mathrm{Mo} / \mathrm{Al}_{2} \mathrm{O}_{3}$ catalyst. Determination of TOF values allows to ascertain the beneficial effect resulting from an optimized incorporation of nickel into cobalt-promoted $\mathrm{MoS}_{2}$ slabs showing that the controlled preparation of aluminasupported trimetallic CoNiMo catalysts is a promising way to enhance the HDS catalytic

performance of $\mathrm{MoS}_{2}$-based solids through addition of nickel onto partly available M-edge planes

\section{Acknowledgments}


We appreciate the support of: SENER-PEMEX through the project 117373, CONACYT project 182191 and CIC-UMSNH 2020. We also appreciate the technical support provided by F. Ruiz, M. Estrada, D. Dominguez, J.A. Díaz, I. Gradilla, E. Aparicio at CNyN-UNAM Mexico. Thanks to E. Guerrero L and W. Antunez for their technical help at NaNoTech CIMAV Mexico.

\section{References}

[1] G. Berhault G, Metal sulfides: novel synthesis methods and recent developments, in: New Materials for Catalytic Applications (V.I. Parvulescu, E. Kemnitz, Eds), Elsevier, Amsterdam, 2016, pp. 313-360. https://doi.org/10.1016/B978-0-444-63587-7.00010-X.

[2] B. Guichard, M, Roy-Auberger, E. Devers, B. Rebours, A.A. Quoineaud, M. Digne, Appl. Catal. A. 367 (2009) 1-8. https://doi.org/10.1016/j.apcata.2009.07.024.

[3] C. Song, X. Ma, Appl. Catal. B 41 (2003) 207-238. https://doi.org/10.1016/S09263373(02)00212-6.

[4] K.H. Choi, Y. Sano, Y. Korai, I. Mochida, Appl. Catal. B 49 (2004) 219-225. https://doi.org/10.1016/j.apcatb.2003.12.007.

[5] H. Farag, I. Mochida, J. Colloid. Interface Sci. 372 (2012) 121-129. https://doi.org/10.1016/j.jcis.2012.01.019.

[6] Z. Liu, Y. Zheng, W. Wang, Q. Zhang, L. Jia, Appl. Catal. A 339 (2008) 209-220 https://doi.org/10.1016/j.apcata.2008.01.018.

[7] A. Stanislaus, A. Marafi, M.S. Rana, Catal. Today 153 (2010) 1-68. https://doi.org/10.1016/j.cattod.2010.05.011. 
[8] S.V. Budukva, P.M. Eletskii, O.O. Zaikina, G.A. Sosnin, V.A. Yakovlev. Secondary Middle Distillates and Their Processing (Review). Petroleum Chemistry 2019; 59(9):941955. https://doi.org/10.1134/S0965544119090044.

[9] I.V. Babich, J.A. Moulijn, Fuel 82 (2003) 607-631. https://doi.org/10.1016/S00162361(02)00324-1.

[10] A. Guevara-Lara, R. Bacaud, M. Vrinat, Appl. Catal. A 328 (2007) 99-108. https://doi.org/10.1016/j.apcata.2007.05.028.

[11] Y. Li, D. Pan, C. Yu, Y. Fan, X. Bao, J. Catal. 286 (2012) 124-136. https://doi.org/10.1016/j.jcat.2011.10.023.

[12] F. Rashidi, T..Sasaki, A.M. Rashidi, A.N. Kharat, K.J. Jozani, J. Catal. 299 (2013) 321335. https://doi.org/10.1016/j.jcat.2012.11.012.

[13] W. Chen, F. Maugé, J. Van Gestel, H. Nie, D. Li, X. Long, J. Catal. 304 (2013) 47-62. https://doi.org/10.1016/j.jcat.2013.03.004.

[14] M. Sun, D. Nicosia, R. Prins, Catal. Today 86 (2003) 173-189. https://doi.org/10.1016/S0920-5861(03)00410-3.

[15] A. López-Benítez, G. Berhault, A. Guevara-Lara, J. Catal. 344 (2016) 59-76. https://doi.org/10.1016/j.jcat.2016.08.015.

[16] A. López-Benítez, G. Berhault, L. Burel, A. Guevara-Lara, J. Catal. 354 (2017) 197212. https://doi.org/10.1016/j.jcat.2017.08.027.

[17] R. Huirache-Acuña, E.M. Rivera-Muñoz, B. Pawelec, M. Ostrooumov, R. MayaYescas, J.L. Rico, Catal. Today 220-222 (2014) 301-309. https://doi.org/10.1016/j.cattod.2013.07.019. 
[18] Z. Vit, D. Gulkova, L. Kaluza, S. Bakardieva, M. Boaro, Appl. Catal. B 100 (2010) 463471. https://doi.org/10.1016/j.apcatb.2010.08.022.

[19] J.A. Schaidle, N.M. Schweitzer, O.T. Ajenifujah, L.T. Thompson, J. Catal. 289 (2012) 210-217. https://doi.org/10.1016/j.jcat.2012.02.012.

[20] J.A. Cecilia, A. Infantes-Molina, E. Rodríguez-Castellón, A. Jiménez-López, J. Catal. 263 (2009) 4-15. https://doi.org/10.1016/j.jcat.2009.02.013.

[21] Y.K. Lee, S.T. Oyama, J. Catal. $239 \quad$ (2006) 376-389. https://doi.org/10.1016/j.jcat.2005.12.029.

[22] A.W. Burns, A.F. Gaudette, M.E. Bussell, J. Catal. 260 (2008) 262-269. https://doi.org/10.1016/j.jcat.2008.10.001.

[23] S.T. Oyama, Y.K. Lee, J. Catal. $258 \quad$ (2008) 393-400. https://doi.org/10.1016/j.jcat.2008.06.023.

[24] G. Berhault, P. Afanasiev, H. Loboué, C. Geantet, T. Cseri, C. Pichon, C. GuillotDeudon, A. Lafond, Inorg. Chem. 48 (2009) 2985-2992. https://doi.org/10.1021/ic802074k. [25] S.T. Oyama, H. Zhao, H.J. Freund, K. Asakura, R. Włodarczyk, M. Sierka, J. Catal. 285 (2012) 1-5. https://doi.org/10.1016/j.jcat.2011.08.006.

[26] A.I. D’Aquino, S.J. Danforth, T.R. Clinkingbeard, B. Ilic, L. Pullan, M.A. Reynolds, B.D. Murray, M.E. Bussell, J. Catal. $335 \quad$ (2016) 204-214. https://doi.org/10.1016/j.jcat.2015.12.006.

[27] H. Zhao, S.T. Oyama, H.J. Freund, R. Włodarczyk, M. Sierka, Appl. Catal. B 164 (2015) 204-216. https://doi.org/10.1016/j.apcatb.2014.09.010.

[28] F. Liu, S. Xu, L. Cao, Y. Chi, T. Zhang, D. Xue, J. Phys. Chem. C 111 (2007) 73967402. https://doi.org/10.1021/jp068482+. 
[29] I. Chorkendorff and J.W. Niemantsverdriet, Concepts of Modern Catalysis and Kinetics, Wiley-VCH Verlag GmbH \& Co. KGaA, 2005, p. 1-21.

[30] M. Hussain, J.S. Yun, S.K. Ihm, N. Russo, F. Geobaldo, Ind. Eng. Chem. Res. 50 (2011) 2530-2535. https://doi.org/10.1021/ie100574w.

[31] M.E. Pacheco, V.M. Martins Salim, J.C. Pino, Ind. Eng. Chem. Res. 502011 59755981. https://doi.org/10.1021/ie1023595.

[32] D.K. Lee, I.C. Lee, S.I. Woo, Appl. Catal. A 109 (1994) 195-210. https://doi.org/10.1016/0926-860X(94)80118-5.

[33] S. Badoga, A. Ganesan, A.K. Dalai, S. Chand, Catal. Today 291 (2017) 160-171. https://doi.org/10.1016/j.cattod.2017.01.005.

[34] O.V. Klimov, K.A. Nadeina, P.P. Dik, G.I. Koryakina, V.Yu. Pereyma, M.O. Kazakov, S.V. Budukva, E.Yu. Gerasimov, I.P. Prosvirin, D.I. Kochubey, A.S. Noskov, Catal. Today 271 (2016) 56-63. https://doi.org/10.1016/j.cattod.2015.11.004.

[35] A.V. Mozhaev, P.A. Nikulshin, A.1.A. Pimerzin, K.I. Maslakov, A.A. Pimerzin, Catal. Today 271 (2016) 80-90. https://doi.org/10.1016/j.cattod.2015.11.002.

[36] C.L. Yin, H. Liu, X.H. Li, Y.P. Wang, B. Liu, L.Y. Zhao, C.G. Liu, Catal. Lett. 144 (2014) 285-292. https://doi.org/10.1007/s10562-013-1131-2.

[37] F. Severino, J. Laine, A. López-Agudo, J. Catal. 189 (2000) 244-246. https://doi.org/10.1006/jcat.1999.2683.

[38] J. Laine, J.L. Brito, F. Severino, J. Catal. 131 (1991) 385-393. https://doi.org/10.1016/0021-9517(91)90273-7.

[39] C. Cáceres, J.L.G. Fierro, A. López Agudo, F. Severino, J. Laine, J. Catal. 97 (1986) 219-227. https://doi.org/10.1016/0021-9517(86)90052-7. 
[40] W. Qian, Y. Hachiya, D. Wang, K. Hirabayashi, A. Ishihara, T. Kabe, H. Okazaki, M. Adachi, Appl. Catal. A 227 (2002) 19-28. https://doi.org/10.1016/S0926-860X(01)00919-X. [41] R. Sadeghbeigi. Fluid Catalytic Cracking Handbook, 2nd Ed. Gulf Professional Publishing, Houston, 2000, p.84.

[42] H. Schweiger, P. Raybaud, H. Toulhoat, J. Catal. 212 (2002) 33-38. https://doi.org/10.1006/jcat.2002.3737.

[43] M. Sun, A.E. Nelson, J. Adjaye, J. Catal. $226 \quad$ (2004) 32-40. https://doi.org/10.1016/j.jcat.2004.05.005.

[44] M. Sun, A.E. Nelson, J. Adjaye, J. Catal. $226 \quad$ (2004) 41-53. https://doi.org/10.1016/j.jcat.2004.04.023.

[45] E. Krebs, B. Silvi, P. Raybaud, Catal. Today 130 (2008) 160-169. https://doi.org/10.1016/j.cattod.2007.06.081.

[46] K. Marchand, C. Legens, D. Guillaume, P. Raybaud, Oil \& Gas Sci tech - Rev. IFP 64 (2009) 719-730. https://doi.org/10.2516/ogst/2009037.

[47] S. Texier, G. Berhault, G. Pérot, F. Diehl, Appl. Catal. A 293 (2005) 105-119. https://doi.org/10.1016/j.apcata.2005.07.026

[48] G. Alonso, G. Berhault, A. Aguilar, V. Collins, C. Ornelas, S. Fuentes, R.R. Chianelli, J. Catal. 208 (2002) 359-369. https://doi.org/10.1006/jcat.2002.3553.

[49] G. Leofanti, M. Padovan, G. Tozzola, B. Venturelli, Catal. Today 41 (1998) 207-219. https://doi.org/10.1016/S0920-5861(98)00050-9.

[50] S. Badoga, R.V. Sharma, A.K. Dalai, J. Adyaje, Appl. Catal. A 489 (2015) 86-97. https://doi.org/10.1016/j.apcata.2014.10.008. 
[51] S. Badoga, K. Chandra Mouli, K.K. Soni, A.K. Dalai, J. Adyaje, Appl. Catal. B 125 (2012) 67-84. https://doi.org/10.1016/j.apcatb.2012.05.015.

[52] N-Q. Bui, C. Geantet, G, J. Catal. $330 \quad$ (2015) 374-386. https://doi.org/10.1016/j.jcat.2015.07.031.

[53] N-Q. Bui, C. Geantet, G. Berhault, Appl. Catal. A 572 (2019) 185-196. https://doi.org/10.1016/j.apcata.2019.01.006.

[54] K. Inamura, K. Uchikawa, S. Matsuda, Y. Akai, Appl. Surf. Sci. 121-122 (1997) 468475. https://doi.org/10.1016/S0169-4332(97)00331-0.

[55] L. Peña, D. Valencia, T. Klimova, Appl. Catal. B 147 (2014) 879-887. https://doi.org/10.1016/j.apcatb.2013.10.019.

[56] Y. Saih, K. Segawa, Appl. Catal. A 353 (2009) 258-265. https://doi.org/10.1016/j.apcata.2008.10.037.

[57] A.N. Desikan, L. Huang, S.T. Oyama, J. Phys. Chem. 95 (1991) 10050-10056. https://doi.org/10.1021/j100177a080.

[58] X. Carrier, J.F. Lambert, M. Che, J. Am. Chem. Soc. 119 (1997) 10137-10146. https://doi.org/10.1021/ja971981r.

[59] A. López-Benítez, G. Berhault, A. Guevara-Lara, Appl. Catal. B 213 (2017) 28-41. https://doi.org/10.1016/j.apcatb.2017.04.058.

[60] M. Ramos, G. Berhault, D.A. Ferrer, B. Torres, R.R. Chianelli, Catal. Sci. Tech. 2 (2012) 164-178. https://doi.org/10.1039/C1CY00126D.

[61] M. Perez De la Rosa, S. Texier, G. Berhault, A. Camacho, M.J. Yácaman, A. Mehta, S. Fuentes, J.A. Montoya, F. Murrieta, R.R. Chianelli, J. Catal. 225 (2004) 288-299. https://doi.org/10.1016/j.jcat.2004.03.039. 
[62] T. Weber, J.C. Muijsers, J.H.M.C. Van Wolput, C.P.J. Verhagen, J.W.

Niemantsverdriet, J. Phys. Chem. 100 (1996) 14144-14150. https://doi.org/10.1021/jp961204y.

[63] J. Lu, P. Qi, Y. Peng, Z. Meng, Z. Yang, W. Yu, Y. Qian, Chem. Mater 13 (2001) 21692172. https://doi.org/10.1021/cm010049j.

[64] Y. Sakashita, Surf. Sci. 489 (2001) 45-58. https://doi.org/10.1016/S00396028(01)01127-X.

[65] A. Galtayries, S. Wisniewski, J. Grimblot, J. Electron Spectros Related Phenomena 87 (1997) 31-44. https://doi.org/10.1016/S0368-2048(97)00071-6.

[66] A.M. Venezia, Catal. Today 77 (2003) 359-370. https://doi.org/10.1016/S09205861(02)00380-2.

[67] J.C. Dupin, D. Gonbeau, I. Martin-Litas, P.h. Vinatier, A. Levasseur, Appl. Surf. Sci. 173 (2001) 140-150. https://doi.org/10.1016/S0169-4332(00)00893-X.

[68] A.D. Gandubert, E. Krebs, C. Legens, D. Costa, D. Guillaume, P. Raybaud, Catal. Today 130 (2008) 149-159. https://doi.org/10.1016/j.cattod.2007.06.041.

[69] D.G. Castner, P.R. Watson, J. Phys. Chem. 95 (1991) 6617-6623. https://doi.org/10.1021/j100170a044.

[70] S.J. Ding, S.J. Jiang, Y.S. Zhou, Q. Wei, W.W. Zhou, J. Catal. 345 (2017) 24-38. https://doi.org/10.1016/j.jcat.2016.11.011. 
Table 1. BET specific surface area, total pore volume and pore diameter of the trimetallic $\mathrm{CoNi} \mathrm{x}_{\mathrm{x}} / \mathrm{Al}_{2} \mathrm{O}_{3}$ catalysts. Comparison to the $\mathrm{CoMo} / \mathrm{Al}_{2} \mathrm{O}_{3}$ reference.

\begin{tabular}{|c|c|c|c|}
\hline $\mathrm{Al}_{2} \mathrm{O}_{3}-$ & Specific & Total pore & Pore \\
\hline Supported & surface area & volume & diameter \\
\hline Sample & $\left(m^{2} \cdot g^{-1}\right)$ & $\left(\mathrm{cm}^{3} \cdot \mathrm{g}^{-1}\right)$ & (nm) \\
\hline CoMo & 157 & 0.46 & 8.52 \\
\hline $\mathrm{CoNi}_{0.01} \mathrm{Mo}$ & 162 & 0.49 & 8.54 \\
\hline $\mathrm{CoNi}_{0.03} \mathrm{Mo}$ & 176 & 0.52 & 8.35 \\
\hline CoNi ${ }_{0.05} \mathrm{Mo}$ & 170 & 0.50 & 8.38 \\
\hline CoNi0.1Mo & 152 & 0.46 & 8.66 \\
\hline
\end{tabular}


Table 2. TEM statistical determination of the $\mathrm{MoS}_{2}$ slab dispersion (average slab length and average stacking number) for $\mathrm{CoMo} / \mathrm{Al}_{2} \mathrm{O}_{3}, \mathrm{CoNi} 0.05 \mathrm{Mo} / \mathrm{Al}_{2} \mathrm{O}_{3}$ and $\mathrm{CoNi} 0.1 \mathrm{Mo} / \mathrm{Al}_{2} \mathrm{O}_{3}$.

\begin{tabular}{lll}
\hline $\mathbf{A l}_{2} \mathbf{O}_{3^{-}}$ & Average & Average \\
Supported & Slab Length & Stacking \\
Sample & $(\mathbf{n m})$ & Number \\
\hline CoMo & 4.7 & 1.83 \\
CoNi $0.05 \mathrm{Mo}$ & 4.9 & 1.86 \\
CoNi ${ }_{0.1} \mathrm{Mo}$ & 5.4 & 2.23 \\
\hline
\end{tabular}


Table 3. ICP-OES analysis of the $\mathrm{Ni}, \mathrm{Co}$, and Mo contents and determination of the $(\mathrm{Co}+\mathrm{Ni}) /(\mathrm{Co}+\mathrm{Ni}+\mathrm{Mo})$ molar ratio. Values in parentheses are theoretical Ni contents.

\begin{tabular}{|c|c|c|c|c|}
\hline $\begin{array}{c}\mathrm{Al}_{2} \mathrm{O}_{3-} \\
\text { Supported } \\
\text { Sample }\end{array}$ & $\begin{array}{l}\text { \% Mo } \\
\text { (wt \%) }\end{array}$ & $\begin{array}{l}\text { \% Co } \\
(w t \%)\end{array}$ & $\begin{array}{c}\text { \% Ni } \\
(\text { wt } \%)\end{array}$ & $\begin{array}{c}(\mathrm{Co}+\mathrm{Ni}) /(\mathrm{Co}+\mathrm{Ni}+\mathrm{Mo}) \\
\text { Molar Ratio }\end{array}$ \\
\hline CoMo & 15.8 & 3.6 & I & 0.27 \\
\hline $\mathrm{CoNi}_{0.01} \mathrm{Mo}$ & 16.0 & 3.5 & $0.02(0.03)$ & 0.26 \\
\hline CoNi ${ }_{0.03} \mathrm{Mo}$ & 16.4 & 3.8 & $0.03(0.09)$ & 0.28 \\
\hline CoNi ${ }_{0.05} \mathrm{Mo}$ & 16.9 & 3.6 & $0.13(0.15)$ & 0.27 \\
\hline $\mathrm{CoNi}_{0.1} \mathrm{Mo}$ & 16.8 & 3.6 & $0.30(0.31)$ & 0.28 \\
\hline
\end{tabular}


Table 4. Respective proportions of the different Mo and Co species obtained from the decomposition of Mo 3d and Ni 2p XPS core level spectra.

\begin{tabular}{|c|c|c|c|c|c|c|}
\hline $\begin{array}{l}\mathrm{Al}_{2} \mathrm{O}_{3-} \\
\text { Supported } \\
\text { Sample }\end{array}$ & $\begin{array}{r}\mathrm{CoO}_{\mathrm{x}} \\
(\%)\end{array}$ & $\begin{array}{c}\text { CoMoS } \\
(\%)\end{array}$ & $\begin{array}{r}\operatorname{CoS}_{\mathbf{x}} \\
(\%)\end{array}$ & $\begin{array}{r}\mathrm{MoO}_{\mathrm{x}} \\
(\%)\end{array}$ & $\begin{array}{c}\mathrm{MoO}_{\mathbf{x}} \mathrm{S}_{\mathbf{y}} \\
(\%)\end{array}$ & $\begin{array}{c}\mathrm{MoS}_{2} \\
(\%)\end{array}$ \\
\hline CoMo & 13.9 & 68.7 & 17.3 & 9.1 & 8.3 & 82.5 \\
\hline $\mathrm{CoNi}_{0.01} \mathrm{Mo}$ & 8.3 & 66.9 & 24.7 & 5.1 & 30.2 & 64.7 \\
\hline CoNi0.03Mo & 10.8 & 63.8 & 25.4 & 15.9 & 8.0 & 76.1 \\
\hline CoNi ${ }_{0.05} \mathrm{Mo}$ & 8.9 & 68.6 & 22.5 & 12.9 & 5.9 & 81.2 \\
\hline $\mathrm{CoNi}_{0.1} \mathrm{Mo}$ & 16.2 & 56.8 & 27.0 & 13.6 & 7.1 & 79.3 \\
\hline
\end{tabular}


Table 5. Initial reaction rate and HYD/DDS ratio in the HDS of dibenzothiophene for the trimetallic $\mathrm{CoNi} \mathrm{x}_{\mathrm{X}} / \mathrm{Al}_{2} \mathrm{O}_{3}$ catalysts. Comparison to the $\mathrm{CoMo} / \mathrm{Al}_{2} \mathrm{O}_{3}$ reference $(\mathrm{T}=623 \mathrm{~K}$, $\mathrm{P}_{\mathrm{H} 2}=44.8$ bars, $0.25 \mathrm{~g}$ catalyst, $2.7 \mathrm{~g} \mathrm{DBT} / 75 \mathrm{~mL}$ decahydronaphthalene).

\begin{tabular}{|c|c|c|}
\hline $\begin{array}{l}\mathrm{Al}_{2} \mathrm{O}_{3-} \\
\text { Supported } \\
\text { Sample }\end{array}$ & $\begin{array}{l}\text { Initial Reaction Rate } \\
\left(10^{-8} \mathrm{~mol}_{\mathrm{DBT}} \cdot \mathrm{gcat}^{-1} \cdot \mathrm{s}^{-1}\right)\end{array}$ & $\begin{array}{c}\text { HYD/DDS } \\
\text { ratio }\end{array}$ \\
\hline CoMo & 63 & 0.249 \\
\hline CoNi0.01Mo & 59 & 0.264 \\
\hline CoNi ${ }_{0.03} \mathrm{Mo}$ & 56 & 0.248 \\
\hline CoNi ${ }_{0.05} \mathrm{Mo}$ & 72 & 0.390 \\
\hline CoNi0.1Mo & 38 & 0.263 \\
\hline
\end{tabular}




\section{Figure captions.}

Figure 1. A) $\mathrm{N}_{2}$ adsorption-desorption isotherms and B) BJH pore size distribution of the supported trimetallic $\mathrm{CoNi} \mathrm{x}_{\mathrm{x}} \mathrm{Mo} / \mathrm{Al}_{2} \mathrm{O}_{3}$ catalysts. Comparison to the $\mathrm{CoMo} / \mathrm{Al}_{2} \mathrm{O}_{3}$ reference.

Figure 2. XRD patterns for supported trimetallic $\mathrm{CoNi} \mathrm{x}_{\mathrm{X}} \mathrm{Mo} / \mathrm{Al}_{2} \mathrm{O}_{3}$ catalysts. Comparison to the $\mathrm{CoMo} / \mathrm{Al}_{2} \mathrm{O}_{3}$ reference.

Figure 3. Raman spectra of supported trimetallic $\mathrm{CoNi} \times \mathrm{Mo} / \mathrm{Al}_{2} \mathrm{O}_{3}$ catalysts. Comparison to the $\mathrm{CoMo} / \mathrm{Al}_{2} \mathrm{O}_{3}$ reference.

Figure 4. SEM images of the alumina-supported catalysts: A) CoMo, B) CoNio.01Mo, C) CoNio.03Mo, D) CoNio.05Mo, E) CoNio.1Mo.

Figure 5. TEM images of the alumina-supported a) CoMo, b) CoNi0.05Mo, and c) CoNi0.1Mo catalysts.

Figure 6. Examples of XPS decomposition of Mo 3d and Co $2 p$ core emission line regions for the CoNi0.05Mo sulfided catalyst. 


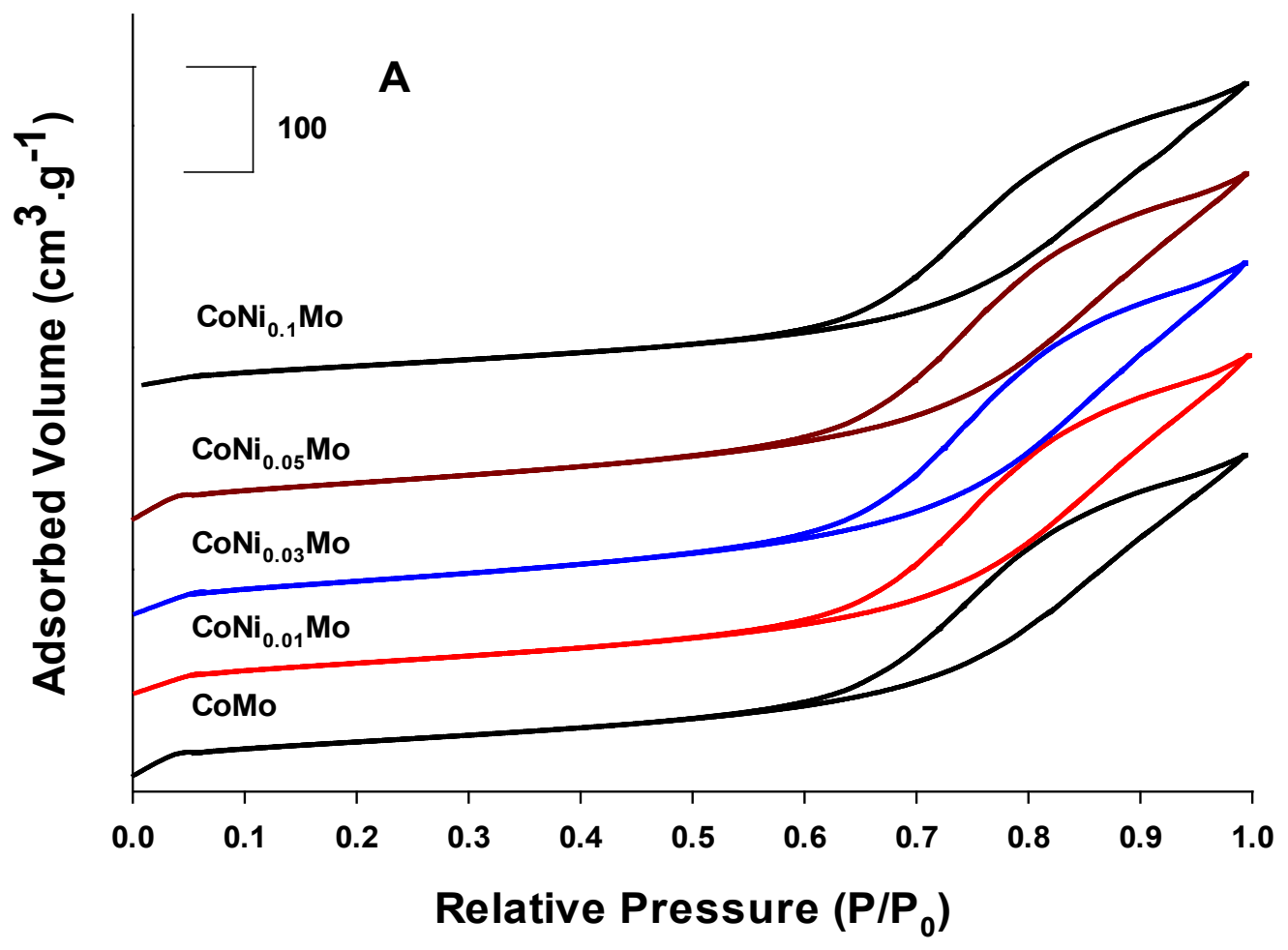




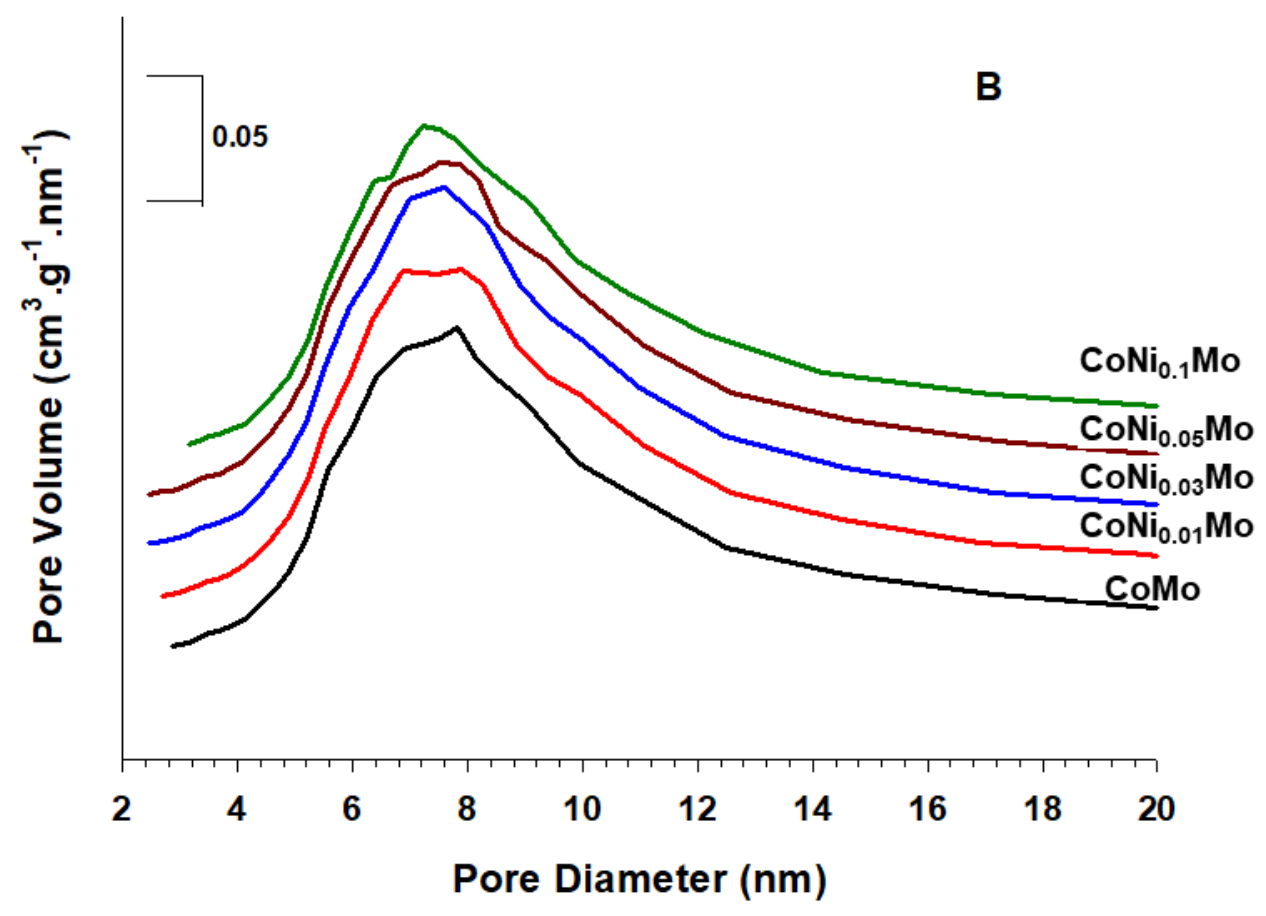

Figure 1. 


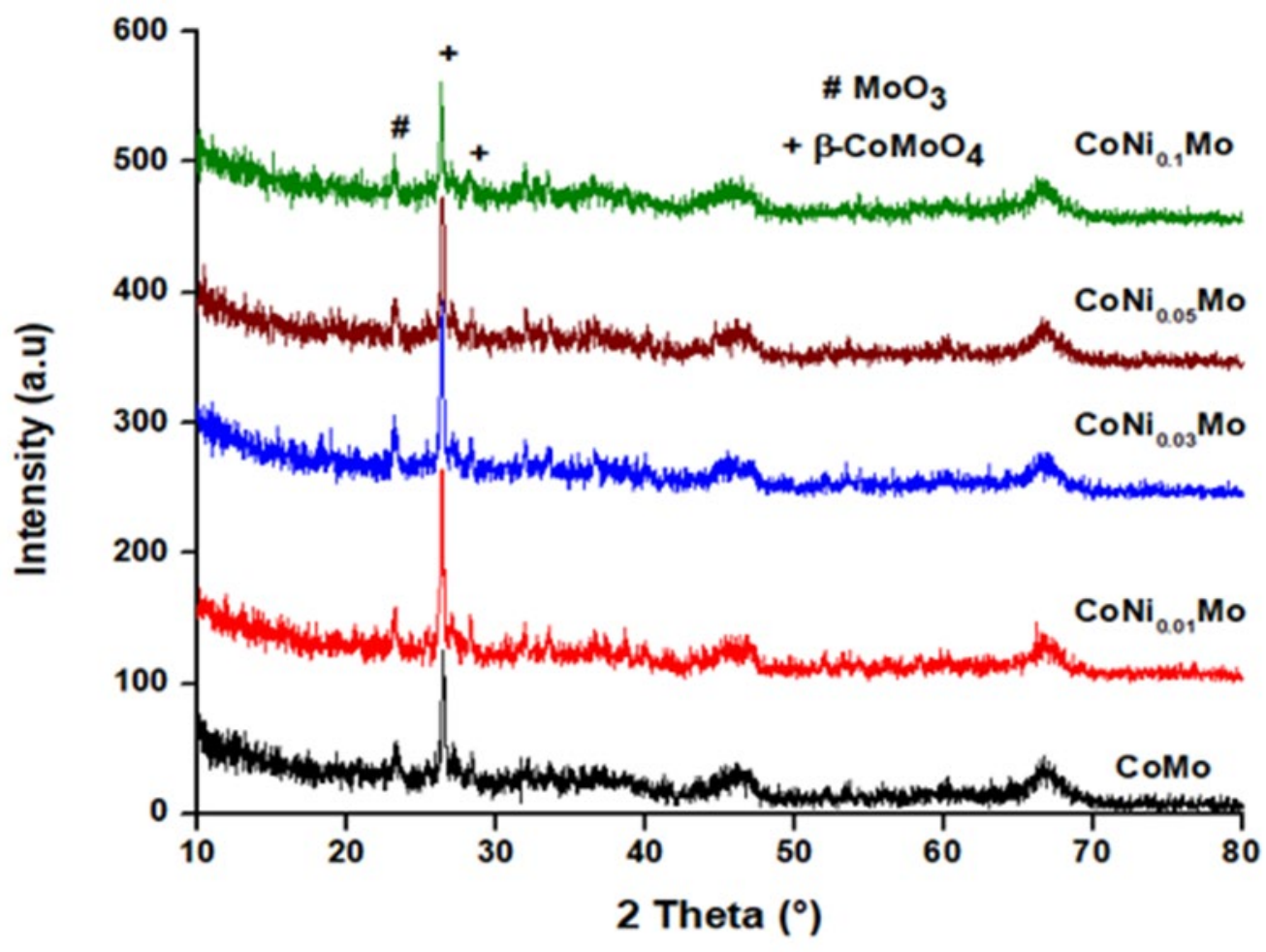

Figure 2. 


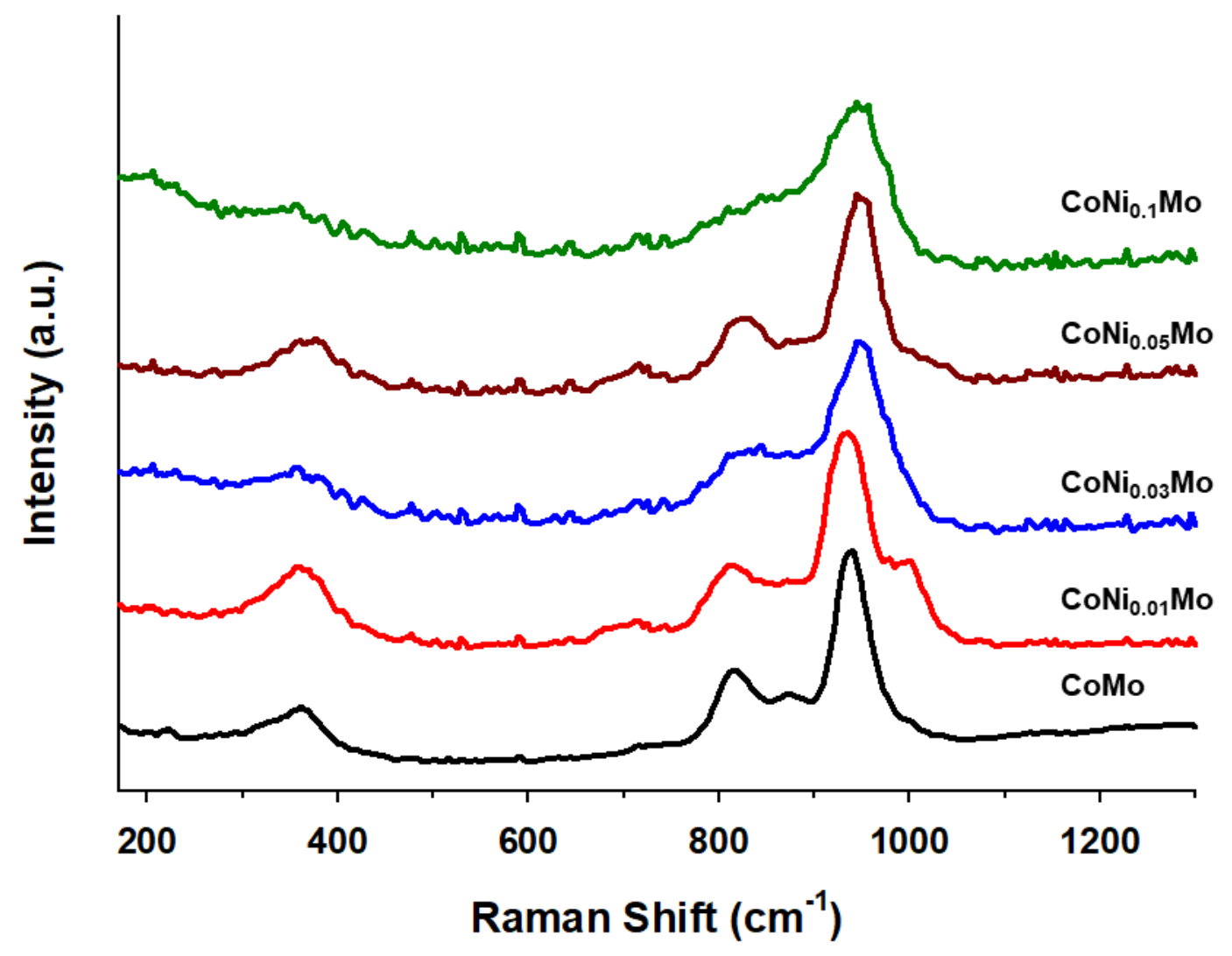

Figure 3. 


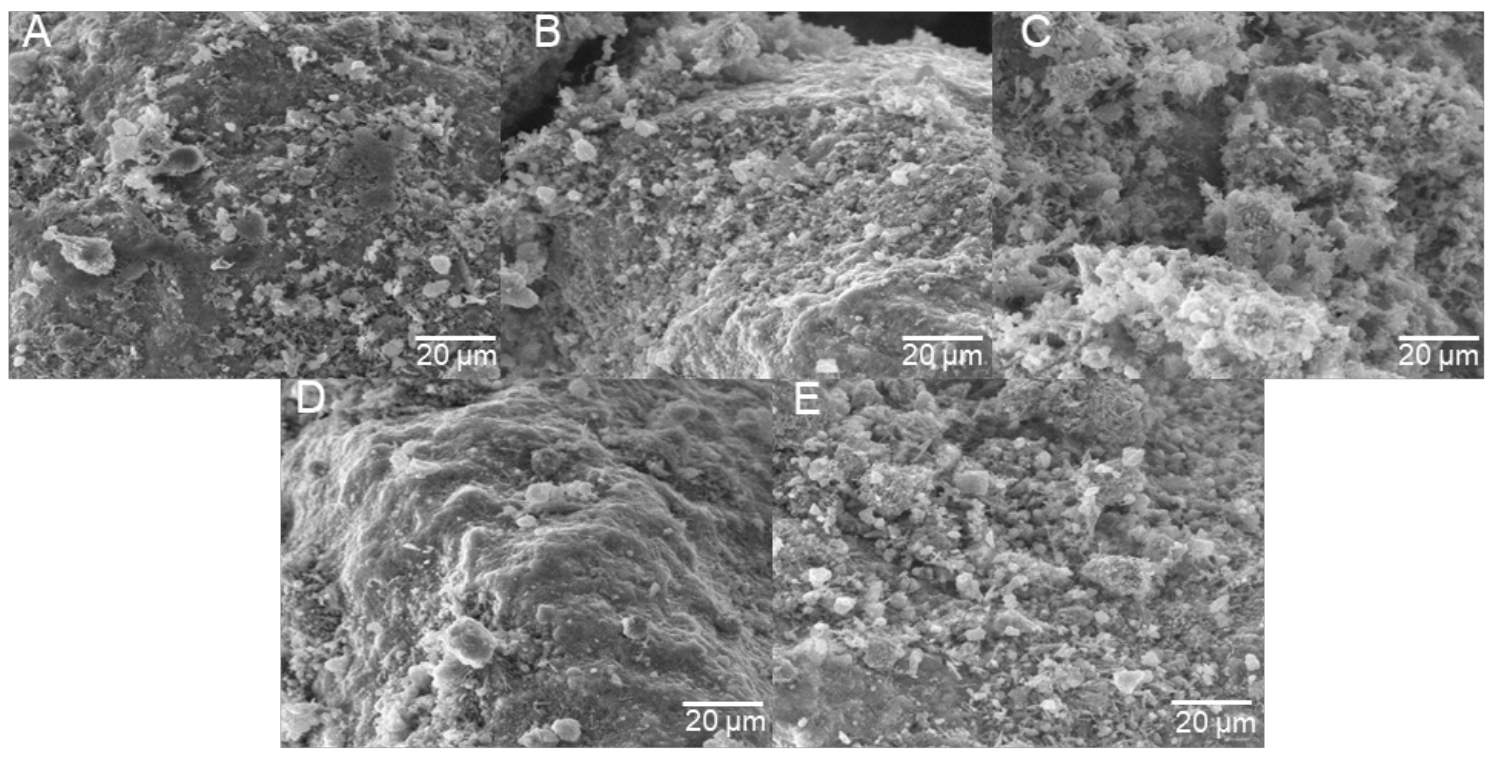

Figure 4. 

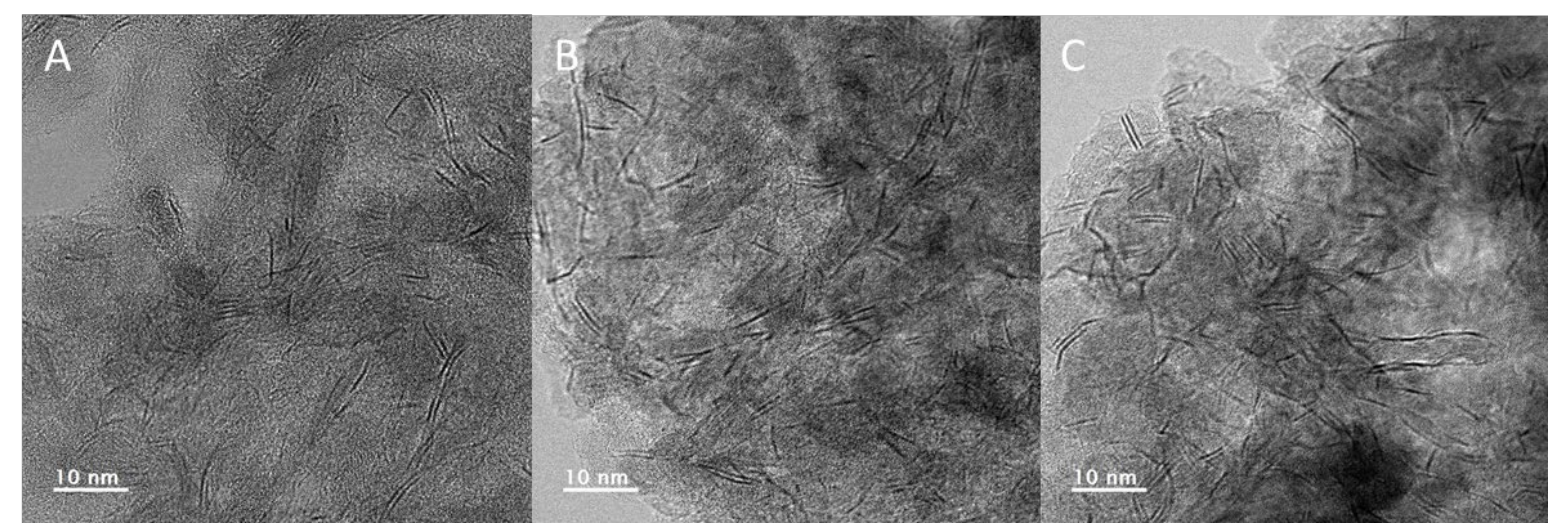

Figure 5. 

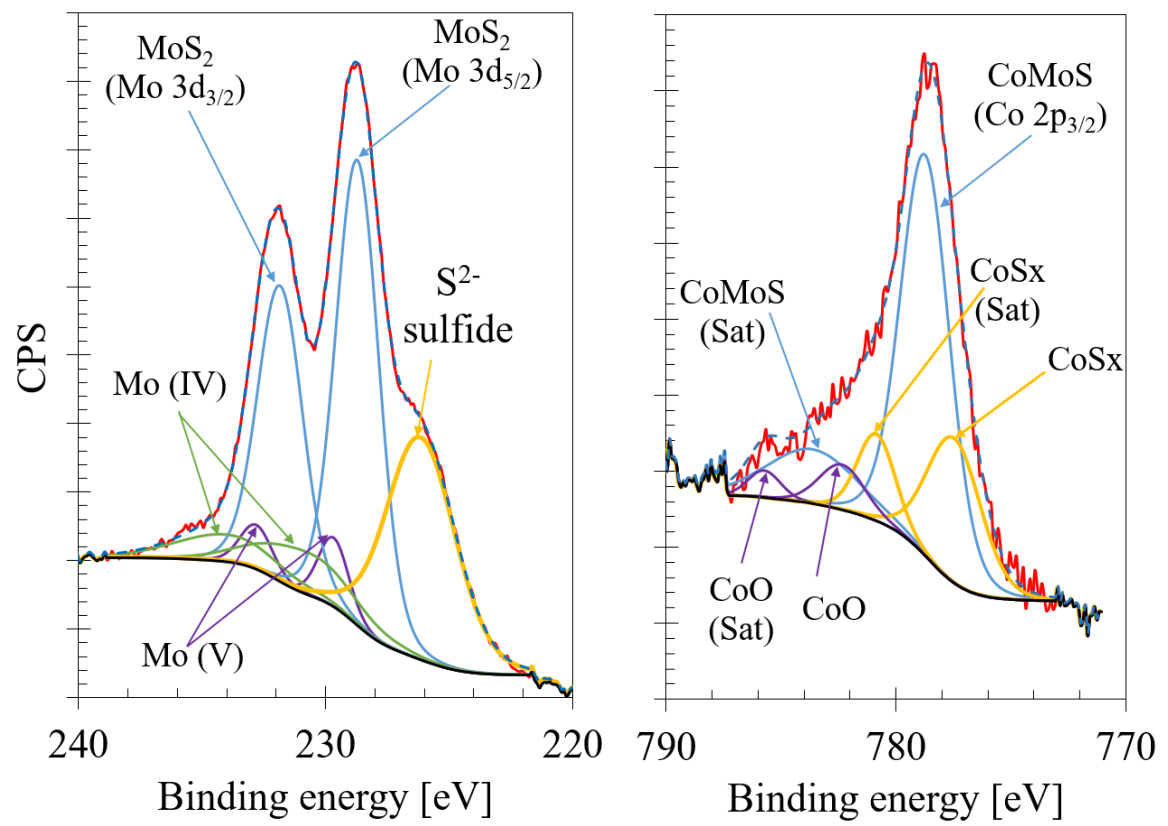

Figure 6 